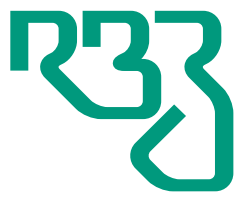

Revista Brasileira de Zootecnia

Brazilian Journal of Animal Science ISSN 1806-9290 www.rbz.org.br

\section{Dietary intake of broiler breeder hens during the laying period affects amino acid and fatty acid profiles in eggs}

\author{
Feng Li ${ }^{1}$ (iD), Yi Yang ${ }^{1}$ (iD), Xue Yang ${ }^{1}$ (iD), Mingxu Shan ${ }^{1}$ (iD), Xiang Gao ${ }^{1}$ (iD), \\ Yuanyuan Zhang ${ }^{1}$ iD, Jingwei Hu${ }^{1}$ iD, Anshan Shan ${ }^{1 *}$ iD \\ ${ }^{1}$ Northeast Agricultural University, College of Animal Science and Technology, Harbin, China.
}

\begin{abstract}
The objective of this study was to evaluate the effects of maternal dietary intake on the amino acid and fatty acid contents in eggs during the laying period. An experiment with a $2 \times 2$ factorial design was conducted with two maternal dietary intake levels ( 100 and $75 \%$ of dietary intake recommended by the Chinese Ministry of Agriculture) and two broiler lines (fat and lean line). A total of 384 hens of fat line and 384 hens of lean line at 23 weeks of age were included in the experiment. Each line was randomly divided into two treatments ( $\mathrm{n}=192$ in each treatment, with 12 replications), and each replication included 16 birds. The treatments were LN (lean line and normal maternal dietary intake, $\mathrm{n}=192$ ), LL (lean line and low maternal dietary intake, $\mathrm{n}=192$ ), FN (fat line and normal maternal dietary intake, $\mathrm{n}=192$ ), and FL (fat line and low maternal dietary intake, $n=192$ ). The amino acid and fatty acid contents in eggs were tested ( 50 weeks of age). The fat line had higher levels of arginine, aspartic acid, glycine, histidine, leucine, methionine, and threonine in the egg albumen than the lean line. Low maternal dietary intake increased the cystine deposition in egg yolks. There were interactions between maternal dietary intake and line on the deposition of trans-oleic acid, docosanoic acid, and total fatty acid in egg yolks. Low maternal dietary intake increased the deposition of tetradecenoic and linolenic acids and the ratio of total polyunsaturated fatty acids to total saturated fatty acid in egg yolks but decreased the deposition of docosanoic acid. Maternal dietary intake and line affect the amino acid and fatty acid profiles in eggs.
\end{abstract}

Keywords: egg albumen, egg yolk, fat line, feed intake, lean line

\title{
Introduction
}

Birds rely entirely on the egg nutrition to sustain life in the initial stage of development. Embryonic development is affected by many factors, including egg nutrition, temperature, and humidity (Dymond et al., 2013; Noiva et al., 2014; Yildirim and Yetisir, 2004). Previous reports have indicated that the changes in egg nutrition affect the embryonic development and health (Bhattacharyya et al., 2018; Kermanshahi et al., 2017). Other researchers have shown that restricting maternal nutrition affects the development of embryos (Prezotto et al., 2016; Raja et al., 2016). In addition, Bhanja et al. (2015) reported that silver nanoparticles and amino acid complexes can act as potential agents to enhance innate and adaptive immunity in chickens. Al-Daraji et al. (2012) reported that the inoculation of different levels of L-Arginine into eggs improves the productive and physiological performance of quail. Moreover, L-Leucine used in ovo injection to increase the prenatal metabolic rate and lipid metabolism (Han et al., 2018). 
Egg nutrition is derived entirely from the mother bird. Some reports have indicated that maternal nutrition changed nutritional composition and characteristics of eggs, which could affect the embryonic development. Many researchers have shown that egg components are affected by dietary components and nutrition level of hens (Güçlü et al., 2008; Li et al., 2011). Our previous work illustrates that the interactions between daily feed intake of hens during the laying period and genotype (fat and lean lines) on egg production, egg weight, percentage yolk, yolk:albumen ratio, and yolk cholesterol content are significant (Li et al., 2011). Maternal feed restriction decreases egg weight and increases egg production, egg-shape index, and cholesterol content of yolk significantly (Li et al., 2011). Lima et al. (2007) reported that different dietary components can affect the characteristics of eggs of commercial laying hens. Besides, Trindade Neto et al. (2011) showed that increasing dietary lysine concentration can reduce the protein content and increase the composition of lipids in eggs. Corduk and Sarica (2008) showed that dietary metabolizable energy (ME) levels or fat sources in layer diets significantly affect egg quality parameters. In addition, different dietary oils or fat sources can affect the fatty acid profile, and no negative effects have been found on the performance of hens, total fat content of eggs, or egg quality (King et al., 2012). Moreover, during embryonic and post-hatching periods, the antioxidant capacity of progeny can be improved by the inclusion of vitamin E, selenium (Se), or methionine (Met) in the maternal diet (Zhao et al., 2010; Surai et al., 2016).

Our previous research showed that low maternal dietary intake affects the embryonic development process, changes the gene expression of myostatin and myogenin (Li et al., 2013), and decreases birth weight of offspring (Li et al., 2019). Although a series of changes in egg weight, egg shape index, and cholesterol content of yolks were found (Li et al., 2011), the effects of maternal nutrition restriction on the fatty acid profile and amino acid profile of eggs, which might affect the embryonic development process and offspring growth, were not clear. We hypothesize that maternal nutrition can affect the amino acids and fatty acids of eggs, which are important nutrients for embryonic development during the hatching period. To better indicate the maternal effects, two broiler lines (fat and lean), differing based on abdominal fat percentage, were used to evaluate the effects of two maternal dietary intake levels on the fatty acid and amino acid profiles in eggs in this study.

\section{Material and Methods}

This study was approved by the Animal Care and Use Committee (case no. 09/2011) and was performed in Harbin, Heilongjiang Province, China $\left(45^{\circ} 75^{\prime} 07^{\prime \prime}\right.$ E longitude, $126^{\circ} 73^{\prime} 39^{\prime \prime} \mathrm{N}$ latitude, and 126 m altitude).

In the experiment, two divergent broiler lines were used: lean and fat lines, which have been selected since 1996 according to abdominal fat percentage, very low deposition of lipoprotein in the plasma, and body weight (Wang et al., 2009). A $2 \times 2$ factorial design was used to research the effects of two maternal dietary intake levels $(100$ and $75 \%$ maternal dietary intake recommended by the Chinese Ministry of Agriculture [CMOA, 2004]) and two broiler lines (fat and lean) on the deposition of amino acids and fatty acids in eggs. Nine hundred one-day-old female birds of fat and lean lines ( 450 birds of each) were used. The birds were reared in stairstep cages from birth to 23 weeks. At 23 weeks old, 768 females (lean line, $n=384$; fat line, $n=384$ ) were randomly selected and assigned to four treatments. Each line was divided into two treatments ( $\mathrm{n}=192$ in each treatment, with 12 replications). Sixteen birds allocated into eight adjoining metal cages consisted of a replicate, and two birds were housed in a cage $(48 \times 34 \times 39 \mathrm{~cm}$ ). The treatments were LN (lean line with normal maternal dietary intake, $\mathrm{n}=192$ ), LL (lean line with low maternal dietary intake, $\mathrm{n}=192$ ), FN (fat line with normal maternal dietary intake, $n=192$ ), and FL (fat line with low maternal dietary intake, $n=192$ ). The initial weight did not significantly differ among individual birds (means: $2.55 \times 10^{3}-2.56 \times 10^{3} \mathrm{~g}$; pooled SEM: $9.13 \mathrm{~g}$ ).

From one day to 24 weeks of age, all birds were supplied with the same diet [0-6 weeks: $12.10 \mathrm{MJ} \mathrm{ME} / \mathrm{kg}$, $179 \mathrm{~g}$ crude protein (CP) $/ \mathrm{kg}$, and $10.6 \mathrm{~g} \mathrm{Ca} / \mathrm{kg} ; 7-18$ weeks: $11.82 \mathrm{MJ} \mathrm{ME} / \mathrm{kg}, 147 \mathrm{~g} \mathrm{CP} / \mathrm{kg}$, and $9.1 \mathrm{~g} \mathrm{Ca} / \mathrm{kg}$; and 19-24 weeks: $11.61 \mathrm{MJ} \mathrm{ME} / \mathrm{kg}, 161 \mathrm{~g} \mathrm{CP} / \mathrm{kg}$, and $20.8 \mathrm{~g} \mathrm{Ca} / \mathrm{kg}$. After 24 weeks, the birds in all treatments were fed a corn-soy-based diet (Table 1). From 27 (5\% of laying rate) to 50 weeks of age, 
the daily feed allocations of the LN and FN treatments (Table 2) were the same as the maternal dietary intake (MDIR) recommended by the Chinese Ministry of Agriculture (CMOA, 2004), and the daily allocations of the LL and FL treatments were reduced to $75 \%$ of MDIR. To alleviate or reduce chronic

Table 1 - Composition of the basal diets of fat-line and lean-line hens

\begin{tabular}{|c|c|c|c|c|}
\hline Item & 1 to 6 weeks & 7 to 18 weeks & 19 to 24 weeks & 24 to 50 weeks \\
\hline \multicolumn{5}{|l|}{ Ingredient (g/kg) } \\
\hline Corn & 678.5 & 731.9 & 686.2 & 628.8 \\
\hline Soybean meal & 282.0 & 196.5 & 231.8 & 235.0 \\
\hline Soybean oil & 4.0 & 0.0 & 0.0 & 0.0 \\
\hline Fish meal & 0.0 & 0.0 & 4.0 & 30.0 \\
\hline Rice hulls & 0.0 & 39.0 & 11.3 & 0.0 \\
\hline Salt & 1.5 & 2.0 & 3.0 & 3.0 \\
\hline $\mathrm{CaHPO}_{4}$ & 17.0 & 15.0 & 20.0 & 16.0 \\
\hline Limestone & 12.5 & 10.6 & 38.5 & 82.0 \\
\hline DL-methionine & 0.2 & 0.7 & 0.8 & 0.8 \\
\hline L-lysine & 0.0 & 0.0 & 0.2 & 0.2 \\
\hline Choline chloride & 1.0 & 1.0 & 1.0 & 1.0 \\
\hline Vitamin premix $^{1}$ & 0.3 & 0.3 & 0.2 & 0.2 \\
\hline Mineral premix ${ }^{2}$ & 3.0 & 3.0 & 3.0 & 3.0 \\
\hline \multicolumn{5}{|l|}{ Nutrient composition ${ }^{3}$} \\
\hline Metabolizable energy $(\mathrm{MJ} / \mathrm{kg}$ ) & 12.10 & 11.82 & 11.61 & 11.64 \\
\hline Crude protein & 179.0 & 147.0 & 161.0 & 170.9 \\
\hline Arginine & 12.0 & 9.3 & 10.5 & 11.4 \\
\hline Histidine & 4.9 & 4.0 & 4.4 & 4.8 \\
\hline Isoleucine & 7.4 & 5.9 & 6.6 & 7.2 \\
\hline Leucine & 16.0 & 13.6 & 14.6 & 15.4 \\
\hline Lysine & 9.2 & 7.0 & 8.2 & 9.2 \\
\hline Methionine & 3.0 & 3.1 & 3.4 & 4.1 \\
\hline Cystine & 3.0 & 2.5 & 2.7 & 2.8 \\
\hline Phenylalanine & 8.7 & 7.1 & 7.8 & 8.3 \\
\hline Tyrosine & 6.2 & 5.2 & 5.6 & 6.0 \\
\hline Threonine & 6.8 & 5.5 & 6.1 & 6.7 \\
\hline Tryptophan & 2.0 & 1.6 & 1.8 & 1.9 \\
\hline Valine & 8.3 & 6.7 & 7.4 & 8.0 \\
\hline Octadecadienoic & 16.4 & 17.1 & 16.3 & 15.1 \\
\hline Calcium & 10.6 & 9.1 & 20.8 & 34.9 \\
\hline Phosphorus & 7.5 & 6.6 & 8.0 & 6.5 \\
\hline Available phosphorus & 4.6 & 4.0 & 5.3 & 4.9 \\
\hline Ether extract & 33.7 & 30.3 & 29.5 & 30.2 \\
\hline Crude fiber & 32.2 & 45.6 & 34.4 & 28.4 \\
\hline Ash & 25.4 & 28.6 & 25.3 & 25.8 \\
\hline Neutral detergent fiber & 105.5 & 99.2 & 99.5 & 94.2 \\
\hline Acid detergent fiber & 48.1 & 41.6 & 43.5 & 42.1 \\
\hline Starch & 440.7 & 471.6 & 443.9 & 407.5 \\
\hline
\end{tabular}

${ }^{1}$ Vitamin premix provided per kilogram of diet: vitamin A, 12,000 IU; cholecalciferol, $2400 \mathrm{IU}$; vitamin E, 30 IU; riboflavin, 9 mg; pantothenic acid, $12 \mathrm{mg}$; niacin, $35 \mathrm{mg}$; cobalamin, $12 \mu \mathrm{g}$; biotin, $0.2 \mathrm{mg}$; folic acid, $1.5 \mathrm{mg}$; thiamine, $2.0 \mathrm{mg}$; pyridoxine, $4.5 \mathrm{mg}$.

${ }^{2}$ Mineral premix provided per kilogram of diet: Fe, 80 mg; Zn, 80 mg; Mn, 100 mg; I, 1.0 mg; Cu, 8 mg; Se, 0.30 mg.

${ }^{3}$ Calculated values. 
stress and hunger, feed was given twice a day at 08:00 and 16:00 h. There was no residual feed each time. Therefore, the feed supply was equal to the maternal dietary intake. Water was given ad libitum during the experimental period. Artificial and natural light were used during the photoperiod: the artificial light was used from 10 days to 29 weeks; a combination of natural and artificial light was used after 29 weeks; from 10 days to 20 weeks, the day length was $8 \mathrm{~h}$; then, from 21 weeks to 29 weeks, it was increased by an average of half an hour per week from $12 \mathrm{~h}$ per day up to a maximum of $16 \mathrm{~h}$ per day, after which was maintained at $16 \mathrm{~h}$ per day. The house temperature was maintained at $20 \pm 2{ }^{\circ} \mathrm{C}$.

Three eggs were randomly selected from each replicate at 16:00 h on the last day of the 50th week of age. The eggs were weighed and broken. Extractions of 100-400 mg albumen and 400-600 mg yolk were used to determine the amino acid levels via the hydrochloric acid hydrolysis method. The external standard curve of amino acids was drawn by the relationship between the concentration and peak area of amino acid (Figure 1). An amino acid analyzer (L-8800 Hitachi Automatic Amino Acid Analyzer, Tokyo, Japan) was used. The length of the ion-exchange column (Hitachi HPLC Packed Column, Hitachi High-Tech Science Corp., Tokyo, Japan) was $4.6 \times 60 \mathrm{~mm}$. A subsample of $0.5 \mathrm{~g}$ well-mixed egg yolk from the same egg used for amino acid determination was weighed and used to determine the fatty acid level via the fatty acid methylation method. Fatty acid methyl esters were analyzed with a Shimadzu GC-2010 gas chromatograph (Shimadzu Scientific Instrument, Inc., Columbia, MD, USA) installed with an SPTM-2560 fused silica capillary column $(100 \mathrm{~m} \times 0.25 \mathrm{~mm} \times 0.2 \mu \mathrm{m}$ film thickness $)$ of Supelco (Sigma-Aldrich, St. Louis, MO, USA), for which a standard with 37 fatty acid methyl esters is available

Table 2 - Feed allocations of fat-line and lean-line hens from 27 to 58 weeks of age ${ }^{1}$

\begin{tabular}{lcc}
\hline \multirow{2}{*}{ Age (weeks) } & \multicolumn{2}{c}{ Feed allocation (g/bird/day) } \\
\cline { 2 - 3 } & Normal maternal dietary intake & Low maternal dietary intake \\
\hline 27 & 150.0 & 112.6 \\
29 & 170.0 & 127.6 \\
33 & 167.0 & 125.4 \\
43 & 163.0 & 122.4 \\
58 & 156.0 & 117.0 \\
\hline
\end{tabular}

${ }^{1}$ Based on the Feeding Standard for Chickens (CMOA, 2004).
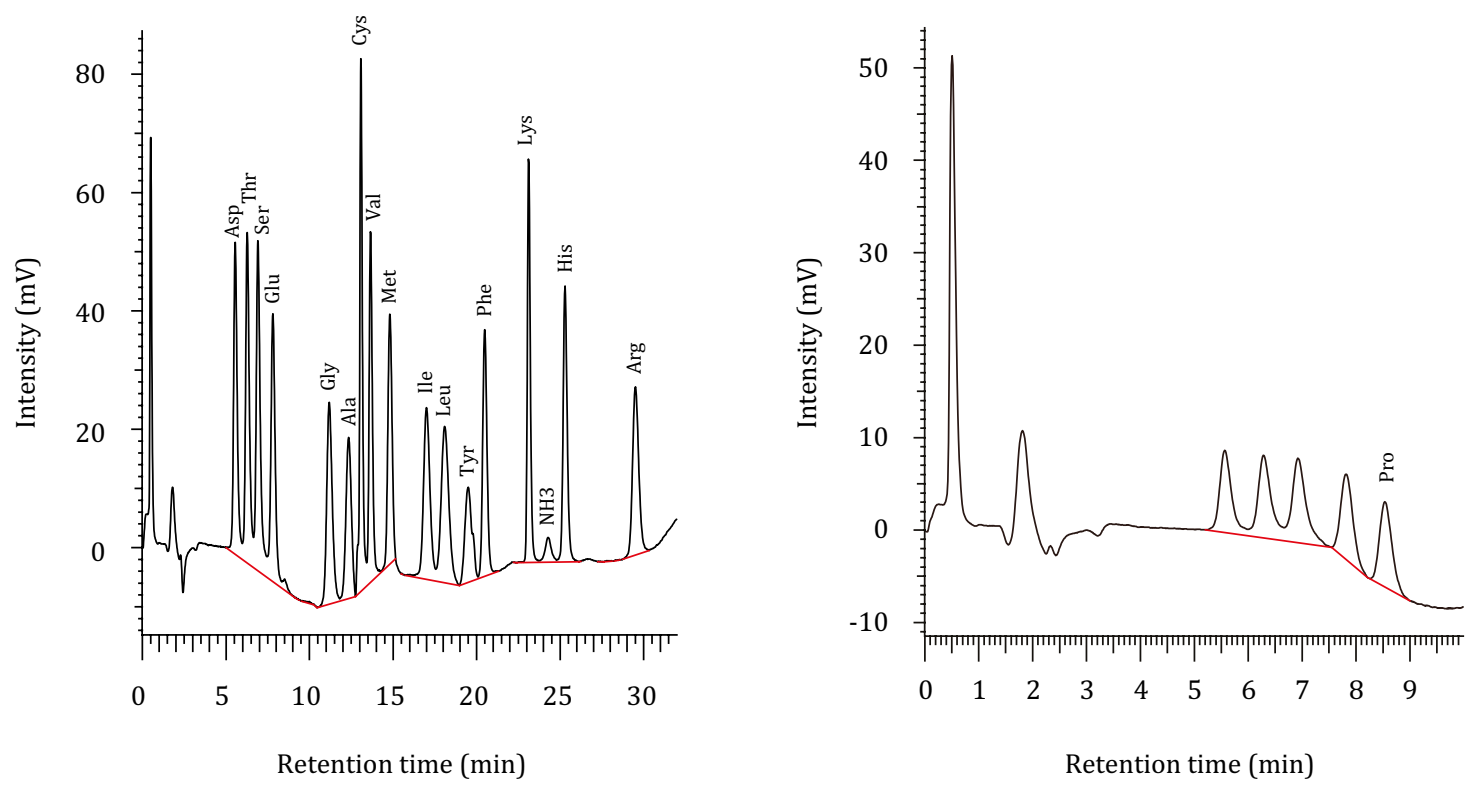

Figure 1 - External standard curve of amino acids. 
(Supelco F.A.M.E. Mix C4-C24, catalog no. 47885-U). The external standard curve of fatty acids was drawn by the relationship between the concentration and peak area of fatty acid (Figure 2).

The hydrochloric acid hydrolysis method was used to determine the amino acid level. The sample was sent to the bottom of a hydrolysis tube, and $6-8 \mathrm{~mL}$ of $6 \mathrm{~mol} / \mathrm{L}$ hydrochloric acid was added to the hydrolysis tube. Each hydrolysis tube was filled with nitrogen, the inner plug was inserted, and the tube was covered with a screw cap. The tubes were placed in an oven at $110{ }^{\circ} \mathrm{C}$ for $22-24 \mathrm{~h}$. After hydrolysis, the tubes were left to cool. The liquid in each tube was well shaken, filtered using filter paper $(11 \times 11 \mathrm{~cm})$, and set to $50 \mathrm{~mL}$ in a volumetric flask with double-distilled water. The hydrolysis tube was washed more than three times with double-distilled water to ensure that the amino acid salts did not remain in the hydrolysis tube or filter paper. Then, $1 \mathrm{~mL}$ liquid was removed from the volumetric flask into a plastic centrifuge tube and concentrated in vacuo for 4-6 $\mathrm{h}$ with a lyophilizer to dryness. Subsequently, $1 \mathrm{~mL}$ of $0.02 \mathrm{~mol} / \mathrm{L}$ hydrochloric acid was added to the centrifuge tube. The tube was well shaken and centrifuged at 14,000 rpm for 15 min with a centrifuge (Anke TDL-60B, Anting Scientific Instrument Factory, Shanghai, China). Then, $0.8 \mathrm{~mL}$ supernatant was filtered through a $0.22 \mathrm{~nm}$ filter membrane into a vial. The vial was placed on an amino acid analyzer (L-8800 Hitachi Automatic Amino Acid Analyzer, Tokyo, Japan). The length of the ion-exchange column (Hitachi HPLC Packed Column, Hitachi High-Tech Science Corp., Tokyo, Japan) was $4.6 \times 60 \mathrm{~mm}$; the resin was 2622\#; the temperature of the reaction column was $135^{\circ} \mathrm{C}$; the temperature of the separation column was $57^{\circ} \mathrm{C}$; the flow rate of the buffer was $0.4 \mathrm{~mL} / \mathrm{min}$; the column pressure was 7.0-7.3 MPa; the flow rate of the ninhydrin was $0.35 \mathrm{~mL} / \mathrm{min}$; and the column pressure was 0.7-0.8 MPa.

The fatty acid methylation method was used to determine the fatty acid level. A sample of $0.5 \mathrm{~g}$ well-mixed egg yolk from the same egg used for the amino acid determination was weighed into a centrifuge tube with a plug. Then, $1.5 \mathrm{~mL}$ ultra-pure water was added and shaken. Heptanoic acid $(0.5 \mathrm{~mL}, 17: 0)$ internal standard solution $(5 \mathrm{mg} / \mathrm{mL}), 2.5 \mathrm{~mL}$ methanol, and $2.5 \mathrm{~mL}$ chloroform were then added and vortexed for $5 \mathrm{~min}$. Two hours later, the mixture was centrifuged at $4200 \mathrm{rpm}$ for $5 \mathrm{~min}$. Then, $1 \mathrm{~mL}$ of the chloroform layer was moved into a screw-capped glass tube and dried in a block heater under a stream of nitrogen. The dried lipids were resolubilized in $2 \mathrm{~mL}$ of sodium methoxide solution. The tubes were heated in a water bath at $50^{\circ} \mathrm{C}$ for $30 \mathrm{~min}$. When cooled, $3 \mathrm{~mL}$ of a hydrochloric acid-methanol solution was added, mixed, sealed, and heated in a water bath at $90{ }^{\circ} \mathrm{C}$ for $60 \mathrm{~min}$. When cooled, $1 \mathrm{~mL}$ double distilled water and $1.5 \mathrm{~mL}$ hexane were added. The sample was mixed and allowed to separate. The hexane (upper) layer was filtered through anhydrous sodium sulfate into a vial for analysis. Fatty acid methyl esters were analyzed with a Shimadzu GC-2010 gas chromatograph (Shimadzu Scientific Instrument, Inc., Columbia, MD, USA) installed with an SPTM-2560 fused silica capillary column (100 m $\times 0.25 \mathrm{~mm} \times 0.2 \mu \mathrm{m}$ film thickness) of Supelco (Sigma-Aldrich, St. Louis, MO, USA), for which a standard with 37 fatty acid methyl esters is available (Supelco F.A.M.E. Mix C4-C24, catalog no. $47885-\mathrm{U})$. The chromatography conditions were as follows: $240{ }^{\circ} \mathrm{C}$ injector temperature;

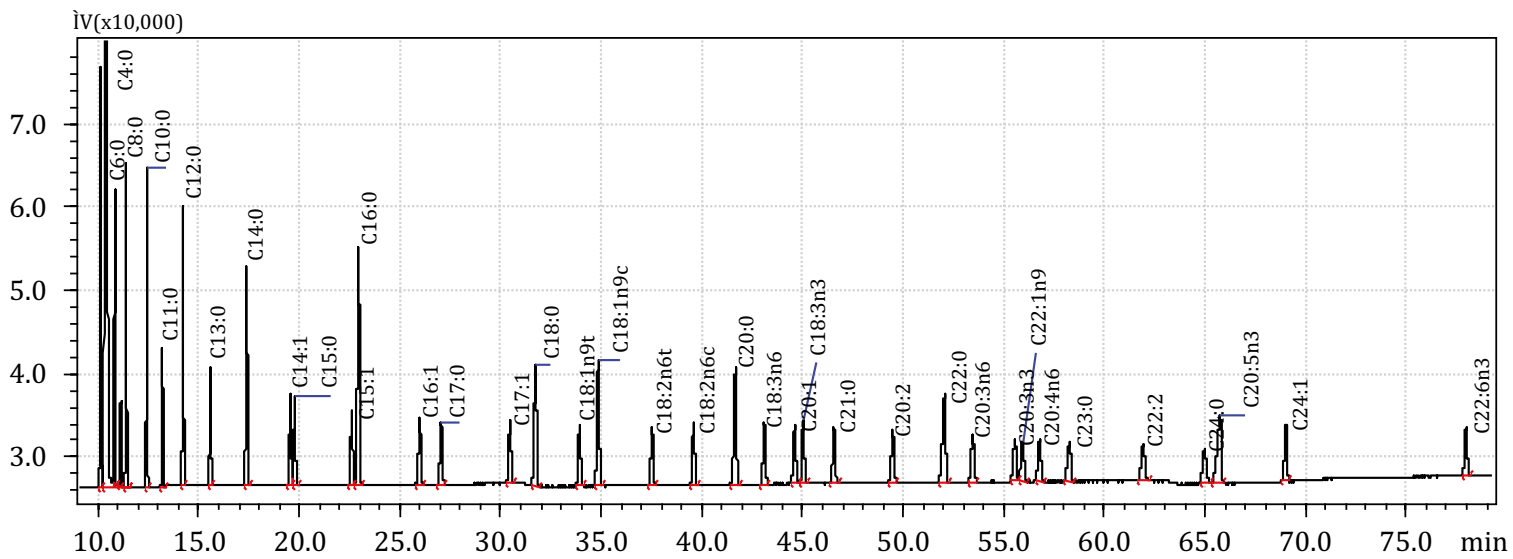

Figure 2 - External standard curve of fatty acids. 
$240{ }^{\circ} \mathrm{C}$ detector temperature; helium as the carrier gas at a flow rate of $1.04 \mathrm{~mL} / \mathrm{min}, 1: 50$ split ratio; and temperature program set to $170{ }^{\circ} \mathrm{C}$ for $30 \mathrm{~min}$, followed by an increase of $1.5^{\circ} \mathrm{C} / \mathrm{min}$ to $200{ }^{\circ} \mathrm{C}$ maintained for $20 \mathrm{~min}$, and then an increase of $5{ }^{\circ} \mathrm{C} / \mathrm{min}$ to $220^{\circ} \mathrm{C}$ maintained for $15 \mathrm{~min}$. Peaks were identified by comparison of retention times with those of the corresponding standards.

Total trait values were analyzed by ANOVA using PROC MIXED of SAS (Statistical Analysis System, version 9.1) for a randomized complete block with a factorial arrangement of treatments. The factorial treatment arrangement consisted of two maternal dietary intake levels and two broiler lines. Maternal dietary intake and lines were fixed effects and blocks were random effects. The following formula was used to calculate the value of amino acid content in the samples:

$$
\mathrm{Yij}=(\mathrm{Wij} \times 2.5) / \mathrm{Wj},
$$

in which Yij = amino acid content in the sample $(\mathrm{mg} / \mathrm{g}), \mathrm{Wij}=$ weight of amino acid measured by the amino acid analyzer, and $\mathrm{Wj}=$ sample weight.

The following formula was used to calculate the value of fatty acid content in the samples:

$$
\mathrm{Yij}=((\mathrm{Fi} \times \mathrm{Wsj} \times \mathrm{Aij}) / \mathrm{Asj}) \times 1000 / \mathrm{Wj},
$$

in which Yij = fatty acid content $(\mathrm{mg} / \mathrm{g}), \mathrm{Fi}=$ correction factor, $\mathrm{Wsj}=$ weight of internal standard mixed with the sample, Aij = peak area of fatty acid, $\mathrm{Asj}=$ peak area of internal standard, $\mathrm{Wj}=$ sample weight, and ( Fi $\times$ Wsj $\times$ Aij) $/$ Asj = fatty acid weight in the sample. In total, 37 mixed external standards contained the internal standard. Fi was calculated using the external standard curve. The calculation formula for $\mathrm{Fi}$ is as follows: $\mathrm{Fi}=(\mathrm{Wi} / \mathrm{Ws}) /(\mathrm{Ai} / \mathrm{As})$, in which $\mathrm{Wi}=$ weight of fatty acid in external standards, Ws = weight of internal standard in external standards, $\mathrm{A} i=$ peak area of fatty acid in the external standard curve, and As = the peak area of internal standard in the external standard curve.

The following model was used to analyze the data:

$$
\text { Yijk }=\mu+\alpha i+\beta j+(\alpha \beta) i j+P k+\varepsilon i j k,
$$

in which Yijk $=$ value of an individual sample from each egg of each replicate, $\mu=$ overall mean, $\alpha \mathrm{i}=$ maternal dietary intake effect, $\beta \mathrm{j}=$ line effect, $(\alpha \beta) \mathrm{ij}=$ interaction between maternal dietary intake and line, $\mathrm{Pk}=$ effect of block, and $\varepsilon \mathrm{ijk}=$ error component. If differences in treatment means were detected by ANOVA, Duncan's multiple range test was applied to separate means. A significance level of $\mathrm{P} \leq 0.05$ was used for analysis.

\section{Results}

The main amino acids in egg albumen were glycine (Gly), alanine (Ala), aspartic (Asp), glutamic acid (Glu), and leucine (Leu) (Table 3). Cysteine (Cys) had the lowest levels in the albumen. There was no significant interaction between maternal dietary intake and line on the deposition of amino acids in egg albumen. There were significant differences $(\mathrm{P}<0.05)$ between the lines in the deposition of Arg, Asp, Gly, histidine (His), Leu, Met, and threonine (Thr) in egg albumen, and the fat line had higher deposition $(\mathrm{P}<0.05)$ of the above amino acids in albumen than the lean line.

The main amino acids in the egg yolks were Gly, Ala, Asp, Glu, Leu, Lysine (Lys), and proline (Table 4). The least abundant amino acid in egg yolk was Cys. There was no significant interaction between maternal dietary intake and line on the deposition of amino acids in egg yolks. There was no significant difference between the lines in the deposition of amino acids in yolks. Low maternal dietary intake significantly increased $(\mathrm{P}<0.05)$ the deposition of Cys in egg yolks. Moreover, low maternal dietary intake significantly increased $(\mathrm{P}<0.05)$ the deposition of amino acids (Met and tyrosine) were not included) in the yolks of the fat line, but there were no significant effects on those of the lean line.

The fatty acids in egg yolks were mainly composed of palmitic (16:0), palmitoleic (16:1), stearic (18:0), oleic (18:1n-9c), and linoleic (18:2n-6c) (Table 5). The deposition of 18:1n-9c in yolks was the highest. There were significant interactions $(\mathrm{P}<0.05)$ between maternal dietary intake and line on the deposition of trans-oleic acid (18:1n-9t), docosanoic acid (22:0), and total fatty acid (TFA) in egg yolks. 
Table 3 - Effect of maternal dietary intake on the deposition of amino acids in egg albumen of fat-line and lean-line hens (mg/g of egg albumen [fresh samples]) $)^{1}$

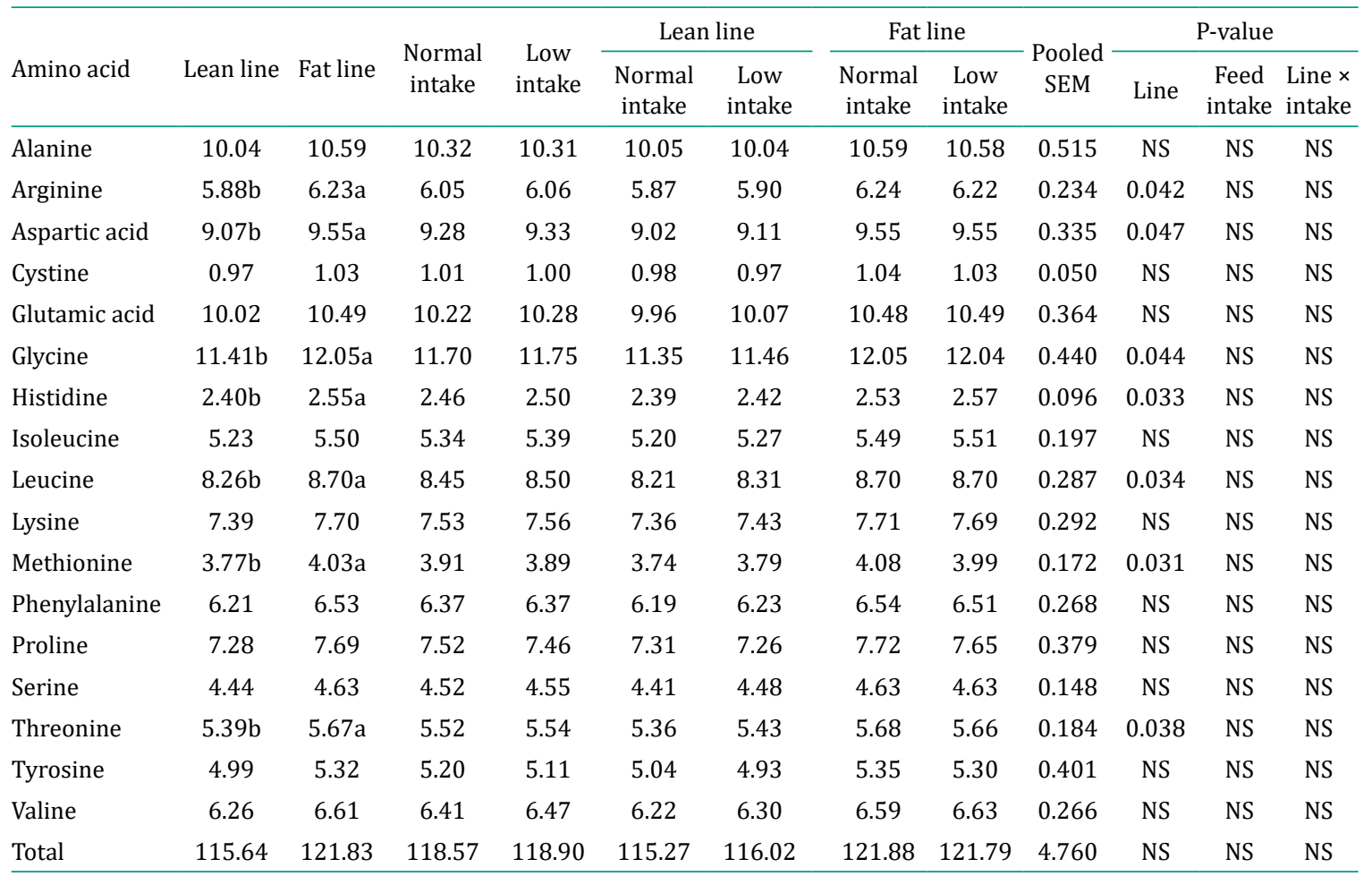

SEM - standard error of the mean; NS - not significant

${ }^{1} \mathrm{n}=36 /$ treatment.

$\mathrm{a}, \mathrm{b}$ - Values within a row with different letters differ significantly at $\mathrm{P}<0.05$.

Table 4 - Effect of maternal dietary intake on the deposition of amino acids in egg yolks of fat-line and lean-line hens (mg/g of egg yolk [fresh samples]) ${ }^{1}$

\begin{tabular}{|c|c|c|c|c|c|c|c|c|c|c|c|c|}
\hline \multirow[b]{2}{*}{ Amino acid } & \multirow[b]{2}{*}{ Lean line } & \multirow[b]{2}{*}{ Fat line } & \multirow{2}{*}{$\begin{array}{l}\text { Normal } \\
\text { intake }\end{array}$} & \multirow{2}{*}{$\begin{array}{c}\text { Low } \\
\text { intake }\end{array}$} & \multicolumn{2}{|c|}{ Lean line } & \multicolumn{2}{|c|}{ Fat line } & \multirow{2}{*}{$\begin{array}{l}\text { Pooled } \\
\text { SEM }\end{array}$} & \multicolumn{3}{|c|}{$P$ value } \\
\hline & & & & & $\begin{array}{c}\text { Normal } \\
\text { intake }\end{array}$ & $\begin{array}{c}\text { Low } \\
\text { intake }\end{array}$ & $\begin{array}{c}\text { Normal } \\
\text { intake }\end{array}$ & $\begin{array}{c}\text { Low } \\
\text { intake }\end{array}$ & & Line & $\begin{array}{c}\text { Feed } \\
\text { intake }\end{array}$ & $\begin{array}{l}\text { Line } x \\
\text { intake }\end{array}$ \\
\hline Alanine & 11.70 & 11.83 & 11.53 & 12.00 & 11.79 & 11.60 & 11.26 & 12.40 & 0.566 & NS & NS & NS \\
\hline Arginine & 10.22 & 10.34 & 10.06 & 10.50 & 10.27 & 10.17 & 9.86 & 10.82 & 0.419 & NS & NS & NS \\
\hline Aspartic acid & 11.47 & 11.44 & 11.25 & 11.67 & 11.55 & 11.39 & 10.95 & 11.94 & 0.433 & NS & NS & NS \\
\hline Cystine & 1.02 & 1.00 & $0.98 b$ & $1.04 \mathrm{a}$ & 1.01 & 1.03 & 0.95 & 1.05 & 0.040 & NS & 0.033 & NS \\
\hline Glutamic acid & 12.26 & 12.07 & 11.93 & 12.39 & 12.31 & 12.20 & 11.56 & 12.58 & 0.461 & NS & NS & NS \\
\hline Glycine & 13.47 & 13.50 & 13.20 & 13.78 & 13.52 & 13.43 & 12.88 & 14.13 & 0.542 & NS & NS & NS \\
\hline Histidine & 3.59 & 3.60 & 3.50 & 3.69 & 3.60 & 3.58 & 3.41 & 3.79 & 0.148 & NS & NS & NS \\
\hline Isoleucine & 7.41 & 7.48 & 7.28 & 7.60 & 7.45 & 7.37 & 7.12 & 7.84 & 0.285 & NS & NS & NS \\
\hline Leucine & 12.09 & 12.10 & 11.84 & 12.34 & 12.12 & 12.05 & 11.57 & 12.63 & 0.442 & NS & NS & NS \\
\hline Lysine & 10.98 & 11.06 & 10.79 & 11.26 & 11.03 & 10.93 & 10.54 & 11.58 & 0.462 & NS & NS & NS \\
\hline Methionine & 3.47 & 3.46 & 3.41 & 3.52 & 3.50 & 3.43 & 3.32 & 3.60 & 0.151 & NS & NS & NS \\
\hline Phenylalanine & 6.26 & 6.20 & 6.07 & 6.40 & 6.23 & 6.29 & 5.90 & 6.50 & 0.244 & NS & NS & NS \\
\hline Proline & 11.09 & 11.34 & 10.99 & 11.43 & 11.15 & 11.03 & 10.83 & 11.84 & 0.474 & NS & NS & NS \\
\hline Serine & 7.27 & 7.27 & 7.12 & 7.41 & 7.30 & 7.23 & 6.95 & 7.60 & 0.279 & NS & NS & NS \\
\hline Threonine & 8.23 & 8.23 & 8.05 & 8.40 & 8.26 & 8.20 & 7.85 & 8.60 & 0.305 & NS & NS & NS \\
\hline Tyrosine & 6.87 & 7.36 & 7.09 & 7.13 & 7.04 & 6.69 & 7.15 & 7.58 & 0.548 & NS & NS & NS \\
\hline Valine & 7.66 & 7.69 & 7.47 & 7.89 & 7.66 & 7.66 & 7.27 & 8.11 & 0.325 & NS & NS & NS \\
\hline Total & 155.29 & 155.95 & 152.45 & 158.80 & 156.00 & 154.58 & 148.90 & 163.01 & 6.250 & NS & NS & NS \\
\hline
\end{tabular}

SEM - standard error of the mean; NS - not significant.

${ }^{1} \mathrm{n}=36 /$ treatment.

a,b - Values within a row with different letters differ significantly at $\mathrm{P}<0.05$. 
Table 5 - Effect of maternal dietary intake on the deposition of fatty acids in egg yolks of fat-line and lean-line hens (mg/g of egg yolk [fresh samples]) ${ }^{1}$

\begin{tabular}{|c|c|c|c|c|c|c|c|c|c|c|c|c|}
\hline \multirow[b]{2}{*}{ Fatty acid } & \multirow{2}{*}{$\begin{array}{l}\text { Lean } \\
\text { line }\end{array}$} & \multirow{2}{*}{$\begin{array}{l}\text { Fat } \\
\text { line }\end{array}$} & \multirow{2}{*}{$\begin{array}{l}\text { Normal } \\
\text { line }\end{array}$} & \multirow{2}{*}{$\begin{array}{l}\text { Low } \\
\text { line }\end{array}$} & \multicolumn{2}{|c|}{ Lean line } & \multicolumn{2}{|c|}{ Fat line } & \multirow{2}{*}{$\begin{array}{l}\text { Pooled } \\
\text { SEM }\end{array}$} & \multicolumn{3}{|c|}{ P value } \\
\hline & & & & & $\begin{array}{l}\text { Normal } \\
\text { intake }\end{array}$ & $\begin{array}{l}\text { Low } \\
\text { intake }\end{array}$ & $\begin{array}{l}\text { Normal } \\
\text { intake }\end{array}$ & $\begin{array}{l}\text { Low } \\
\text { intake }\end{array}$ & & Line & $\begin{array}{l}\text { Feed } \\
\text { intake }\end{array}$ & $\begin{array}{l}\text { Line } \times \\
\text { intake }\end{array}$ \\
\hline Tetradecenoic (14:1) & 0.21 & 0.24 & $0.20 \mathrm{~b}$ & $0.25 a$ & 0.20 & 0.22 & 0.19 & 0.29 & 0.039 & NS & 0.047 & NS \\
\hline Palmitic (16:0) & 82.31 & 83.79 & 84.48 & 81.62 & 85.72 & 78.89 & 83.23 & 84.35 & 3.384 & NS & NS & NS \\
\hline Palmitoleic (16:1) & 10.37 & 10.79 & 10.43 & 10.73 & 10.95 & 9.80 & 9.91 & 11.66 & 1.242 & NS & NS & NS \\
\hline Heptadecanoic (17:0) & 4.58 & 4.92 & 4.58 & 4.91 & 4.31 & 4.84 & 4.86 & 4.98 & 0.280 & NS & NS & NS \\
\hline Stearic (18:0) & 24.88 & 26.07 & 26.20 & 24.74 & 26.36 & 23.39 & 26.04 & 26.10 & 1.065 & NS & NS & NS \\
\hline $\begin{array}{l}\text { Trans oleic acid } \\
(18: 1 n-9 t)\end{array}$ & 0.35 & 0.40 & 0.37 & 0.38 & $0.38 \mathrm{ab}$ & $0.32 \mathrm{~b}$ & $0.36 \mathrm{~b}$ & $0.45 \mathrm{a}$ & 0.039 & NS & NS & 0.009 \\
\hline Oleic acid (18:1n-9c) & 134.96 & 140.75 & 138.72 & 136.99 & 142.34 & 127.57 & 135.09 & 146.41 & 10.877 & NS & NS & NS \\
\hline Linoleic (18:2n-6c) & 40.28 & 42.62 & 39.19 & 43.71 & 39.65 & 40.92 & 38.72 & 46.51 & 4.005 & NS & NS & NS \\
\hline Linolenic (18:3n-6) & 0.36 & 0.36 & $0.33 \mathrm{~b}$ & $0.39 \mathrm{a}$ & 0.35 & 0.37 & 0.32 & 0.41 & 0.029 & NS & 0.012 & NS \\
\hline $\begin{array}{l}\text { Heneicosanoic acid } \\
(21: 0)\end{array}$ & $0.06 \mathrm{~b}$ & $0.09 \mathrm{a}$ & 0.07 & 0.08 & 0.06 & 0.06 & 0.09 & 0.10 & 0.014 & 0.002 & NS & NS \\
\hline Docosanoic (22:0) & 0.11 & 0.11 & $0.12 \mathrm{a}$ & $0.09 \mathrm{~b}$ & $0.15 \mathrm{a}$ & $0.07 \mathrm{c}$ & $0.10 \mathrm{bc}$ & $0.12 \mathrm{ab}$ & 0.020 & NS & 0.033 & 0.002 \\
\hline $\begin{array}{l}\text { Eicosatrienoic } \\
(20: 3 n-6)\end{array}$ & 0.49 & 0.50 & 0.46 & 0.52 & 0.49 & 0.48 & 0.44 & 0.56 & 0.051 & NS & NS & NS \\
\hline$\sum \mathrm{TFA}^{2}$ & 314.61 & 326.44 & 320.87 & 320.19 & $326.90 \mathrm{ab}$ & $302.34 b$ & $314.84 \mathrm{ab}$ & $338.05 a$ & 16.663 & NS & NS & 0.049 \\
\hline$\sum \mathrm{SFA}^{3}$ & 113.47 & 116.56 & 117.02 & 113.01 & 118.20 & 108.75 & 115.85 & 117.27 & 4.287 & NS & NS & NS \\
\hline$\sum$ MUFA $^{4}$ & 146.74 & 153.02 & 150.59 & 149.17 & 154.75 & 138.73 & 146.42 & 159.62 & 11.107 & NS & NS & NS \\
\hline$\sum \mathrm{PUFA}^{5}$ & 54.40 & 56.87 & 53.26 & 58.01 & 53.95 & 54.86 & 52.57 & 61.16 & 4.256 & NS & NS & NS \\
\hline$\sum n-6$ & 47.44 & 49.91 & 46.30 & 51.06 & 46.92 & 47.97 & 45.68 & 54.15 & 4.150 & NS & NS & NS \\
\hline$\sum n-3$ & 6.66 & 6.65 & 6.65 & 6.65 & 6.74 & 6.58 & 6.56 & 6.73 & 0.391 & NS & NS & NS \\
\hline$\sum$ PUFA: $\sum$ SFA ratio & 4.80 & 4.89 & $4.55 b$ & $5.15 a$ & 4.54 & 5.07 & 4.56 & 5.23 & 0.343 & NS & 0.020 & NS \\
\hline
\end{tabular}

SEM - standard error of the mean; NS - not significant.

${ }^{1} \mathrm{n}=36 /$ treatment.

${ }^{2}$ Total fatty acids $=16: 0+17: 0+18: 0+21: 0+22: 0+14: 1+16: 1+18: 1 n-9 t+18: 1 n-9 c+18: 2 n-6 c+18: 3 n-6+20: 3 n-6$.

${ }^{3}$ Saturated fatty acids $=16: 0+17: 0+18: 0+21: 0+22: 0$.

${ }^{4}$ Monounsaturated fatty acids $=14: 1+16: 1+18: 1 n-9 t+18: 1 n-9 c$

${ }^{5}$ Polyunsaturated fatty acids $=18: 2 n-6 c+18: 3 n-6+20: 3 n-6$.

a,b,c - Values within a row with different letters differ significantly at $\mathrm{P}<0.05$.

Furthermore, there was a significant difference $(\mathrm{P}<0.01)$ between the two lines in the deposition of heneicosanoic acid (21:0) in egg yolk. In $\mathrm{LN}$ and FN, there was a significant difference $(\mathrm{P}<0.05)$ between the two lines in the deposition of 22:0 in egg yolks. Besides, in LL and FL, there was a significant difference $(\mathrm{P}<0.05)$ between the two lines in the deposition of 18:1n-9t, 22:0, and TFA in egg yolks. Low maternal dietary intake significantly increased the deposition of 14:1, linolenic acid (18:3n-6), and the ratio of total polyunsaturated fatty acids (PUFA) to total saturated fatty acids (SFA) in egg yolk $(\mathrm{P}<0.05)$, but it decreased the deposition of 22:0 $(\mathrm{P}<0.05)$. In terms of the fat line, low maternal dietary intake significantly increased the deposition of 18:1n9t $(\mathrm{P}<0.05)$.

\section{Discussion}

Egg composition, especially the content of amino acids and fatty acids, is critical for the development of an embryo. Egg composition is mainly affected by age, feeding, and variety (Hammershøj and Johansen, 2016). In this experiment, lines might have affected the development of hatching offspring. There were significant differences between the lines in the deposition of many amino acids in albumen, such as Arg, Asp, Gly, His, Leu, Met, and Thr, which might affect the development of hatching offspring. However, no differences in the total deposition in albumen were found between the lines. Furthermore, there was no significant difference between lines in the deposition in yolks. In addition, research by Yin et al. (1996) showed that Met could affect the development of hatching offspring. These results indicated 
that selecting divergently for abdominal fat did not change the total deposition level of amino acids in egg albumen and yolks, despite the difference in abdominal fat percentage $(4.28 \%$ in the fat line and $1.22 \%$ in the lean line) at seven weeks of age (Wang et al., 2009).

In terms of fatty acid deposition, this selection for abdominal fat also caused no significant differences between the lines. A significant line effect on the deposition of 21:0 in egg yolk was found. Moreover, in LL and FL, there were significant differences between the lines in the deposition of 18:1n-9t, 22:0, and TFA. In terms of LN and FN, there was a significant difference between the lines in the deposition of 22:0. These results may be related to abdominal fat percentage.

The contents of amino and fatty acids in maternity are very important for the development of the embryo and are related to their deposition in eggs. Studying the changes in amino and fatty acids in eggs laid by hens with different maternal dietary intake levels may help to explain the nutritional mechanism controlling embryonic development through maternal nutrition. Under healthy circumstances, maternal blood, body tissues, and eggs are in a state of dynamic equilibrium. Generally, the amino acids in the embryo are derived from the decomposition of the small intestine and the maternal dietary intake (Heo et al., 2015). Amino acids in the feed are absorbed into the blood. The amino acids are fed directly into the fallopian tube and ovaries. The content of amino acids deposited in egg yolk and albumen by feeding is approximately $15-20 \%$ of the total amount (Salter et al., 1971). Therefore, the proportions of amino acids in eggs should be similar to the proportions of amino acids in the hen.

Lysine, Met, and Thr are the essential amino acids. With adequate maternal dietary intake of amino acids, this dynamic balance can be maintained. At this time, hen egg yield and egg production may be maintained at a high level. With insufficient maternal dietary intake of amino acids, body tissues in hens will be broken down to meet the amino acid needs of laying eggs (Yin et al., 1996). This situation would destroy the dynamic equilibrium and probably cause weight loss in the hens.

In this experiment, low maternal dietary intake significantly increased the deposition of 17 amino acids in egg yolks. Different levels of protein in the diet had little effect on the protein content and chemical composition of egg. When the protein level in the diet rose from 8 to $13 \%$, the amino acid content and amino acid ratio in the egg did not change significantly (Yin et al., 1996). However, the protein content in eggs increased when the protein level in the diet rose from 11 to $16 \%$ (Babatunde and Fetuga, 1976). Similar to the findings of Yin et al. (1996), low maternal dietary intake did not significantly change the amounts of 17 amino acids in egg albumen and yolk in this experiment (except Cys in yolk).

Dietary factors can affect the deposition of amino acids in eggs. Nimalaratne et al. (2011) reported a significant difference in the deposition of amino acids of egg yolks between two groups whose hens were fed two different diets. These effects are mainly related to the source of amino acids in the feed. The addition of free Met or Cys to the diet of hens had no effect on the Met or Cys content of the egg (Csonka et al., 1947; Carvalho et al., 2018), but those in peptide bondage could increase their level in yolk (Csonka, 1950).

In this research, similarly, $0.08 \%$ free Met was added to the diet. Therefore, more free Met was taken in the normal dietary intake group, but there was no increase of Met in the yolk. Csonka (1950) reported that the Cys:Met ratio increases in the egg yolk during the low protein dietary regimen. In this experiment, low maternal dietary intake increased the deposition of Cys in egg yolks. This was most probably due to the low maternal dietary intake that improved the conversion of Cys from hens to eggs. In the case of low protein intake, Cys is deposited more efficiently in the yolk. Further research is needed to understand the mechanism of the change in the amount of Cys in egg yolk caused by maternal low protein intake.

In this experiment, low maternal dietary intake increased the deposition of most amino acids in egg yolks of the fat line but did not affect those amino acids of the lean line. Usually, the amino acid content in egg yolks is affected by egg yolk weight and fatty acid content. These results may be related to the mobilization and deposition of fatty acids in the fat line.

Chickens are an oviparous animal. Chicken embryonic development is carried out in a closed environment, and the environment can protect the embryo from many external factors. These characteristics make this animal of particular value to biologists in many aspects of research. 
The energy and nutrients needed for the development of chicken embryos are mainly provided by the nutrients stored in the eggs. Egg yolk provides $90 \%$ of the energy needed for embryonic development in the form of fatty acids (Haron et al., 2017). Whether polar or neutral fatty acids, the fatty acids most absorbed by the embryo were 16:0, 16:1, 18:0, 18:1n-9c, and 18:2n-6c, followed by 14:1, 17:0, 18:1n-9t, 18:3n-6, and 20:3n-6.

Unsaturated fatty acids (UFA) can promote growth, eliminate free radicals, reduce blood cholesterol, and improve blood rheology and microcirculation (Cobos et al., 2000). The 18:1n9c and 18:3n6 are essential amino acids for birds. These amino acids can promote metabolism and prevent certain diseases. In this experiment, low maternal dietary intake significantly increased the deposition of $14: 1$ and 18:3n- 6 . However, in terms of 18:2n-6c, there was no significant difference between the two different maternal dietary intakes.

Dietary fatty acid composition can affect the fatty acid composition in egg yolks, which may affect the embryonic development and hatching rate (Kraisoon et al., 2018). The fatty acid 16:0 in the diet can increase the level of $18: 1 \mathrm{n}-9 \mathrm{c}$ in the egg yolk and the level of 18:2n-6c in the embryo, which meet the requirements of embryonic growth and hatching. Adding corn oil, 16:0, 18:1n-9c, or 18:2n-6c to the basal diet could increase the hatchability and reduce embryo mortality at the later stages of hatching (Vilchez et al., 1990). Supplementation with 16:0 could improve the growth of egg yolk, and corn oil could increase the content of 18:2n-6c in eggs, which has been shown to increase embryonic survival and hatching and alter fat metabolism of the offspring (Vilchez et al., 1990; Vilchez et al., 1992). These studies show that different proportions of fatty acids in the diet can influence the ratio of fatty acids in eggs and embryonic development.

From the aspect of feed intake, free fatty acids and very-low deposition lipoprotein in serum could be increased by low maternal dietary intake, which shows that a low maternal dietary intake severely affects lipid metabolism in broilers (Zhan et al., 2007). Moreover, according to Li et al. (2018), a low maternal dietary energy level could improve serum low-deposition lipoprotein-cholesterol level and affect lipid metabolism in embryos. These changes in lipid metabolism (fatty acid compositions in plasma) were caused by changes in fatty acid deposition in yolk, and changes in fatty acid deposition were caused by maternal dietary intake. Similarly, we also found that reducing the dietary intake of hens can cause changes in fatty acid patterns. In our experiments, low maternal dietary intake increased the levels of certain UFA in yolks and the ratio of total PUFA to total SFA, which might affect the development of embryos.

\section{Conclusions}

There are significant interactions between feed intake and line on the deposition of some kinds of fatty acids in egg yolks. The fat line has higher deposition of several kinds of amino acids in the albumen than the lean line. Low maternal dietary intake increases the deposition of cystine in egg yolk and changes the fatty acid profiles of egg yolk.

\section{Conflict of Interest}

The authors declare no conflict of interest.

\section{Author Contributions}

Conceptualization: F. Li and A. Shan. Data curation: F. Li, Y. Yang, M. Shan, J. Hu and A. Shan. Formal analysis: F. Li, Y. Yang, M. Shan, X. Gao, Y. Zhang, J. Hu and A. Shan. Funding acquisition: A. Shan. Investigation: M. Shan, X. Gao, Y. Zhang, J. Hu and A. Shan. Methodology: Y. Yang, X. Yang, M. Shan, X. Gao, Y. Zhang and A. Shan. Project administration: A. Shan. Resources: A. Shan. Software: F. Li and X. Yang. Supervision: A. Shan. Validation: A. Shan. Visualization: A. Shan. Writing-original draft: F. Li, Y. Yang, X. Yang and A. Shan. Writing-review \& editing: F. Li, Y. Yang, X. Yang and A. Shan. 


\section{Acknowledgments}

We thank the Poultry Breeding Group of the College of Animal Science and Technology of the Northeast Agricultural University for providing the birds. This study was supported by the Education Department Research Program of Heilongjiang Province [12531006].

\section{References}

Al-Daraji, H. J.; Al-Mashadani, A. A.; Al-Hayani, W. K.; Al-Hassani, A. S. and Mirza, H. A. 2012. Effect of in ovo injection with L-arginine on productive and physiological traits of Japanese quail. South African Journal of Animal Science 42:139-145. https://doi.org/10.4314/sajas.v42i2.6

Babatunde, G. M. and Fetuga, B. L. 1976. Effects of protein levels in the diets of layers on the egg production rate and the chemical composition of poultry eggs in the tropics. Journal of the Science of Food and Agriculture 27:454-462. https://doi.org/10.1002/jsfa.2740270512

Bhanja, S. K.; Hotowy, A.; Mehra, M.; Sawosz, E.; Pineda, L.; Vadalasetty, K. P.; Kurantowicz, N. and Chwalibog, A. 2015. In ovo administration of silver nanoparticles and/or amino acids influence metabolism and immune gene expression in chicken embryos. International Journal of Molecular Sciences 16:9484-9503. https://doi.org/10.3390/ijms16059484

Bhattacharyya, A.; Majumdar, S.; Bhanja, S. K.; Mandal, A. B. and Kadam, M. 2018. Effect of maternal dietary manipulation and in ovo injection of nutrients on the hatchability indices, post-hatch growth, feed consumption, feed conversion ratio and immunocompetence traits of turkey poults. Journal of Applied Animal Research 46:287-294 https://doi.org/10.1080/09712119.2017.1296843

Carvalho, T. S. M.; Sousa, L. S.; Nogueira, F. A.; Vaz, D. P.; Saldanha, M. M.; Triginelli, M. V.; Pinto, M. F. V. S.; Baiao, N. C. and Lara, L. J. C. 2018. Digestible methionine+cysteine in the diet of commercial layers and its influence on the performance, quality, and amino acid profile of eggs and economic evaluation. Poultry Science 97:2044-2052. https://doi.org/10.3382/ps/pey036

CMOA - Chinese Ministry of Agriculture. 2004. Feeding standard of chicken. Agricultural industry standard, Chinese Ministry of Agriculture, China, NY/T 33.

Cobos, A.; Veiga, A. and Díaz, 0. 2000. Chemical and fatty acid composition of meat and liver of wild ducks (Anas platyrhynchos). Food Chemistry 68:77-79. https://doi.org/10.1016/S0308-8146(99)00164-8

Corduk, M. and Sarica, S. 2008. Effects of L-carnitine in layer diets containing different fat sources and energy levels on hen performance and egg quality. South African Journal of Animal Science 38:260-270.

Csonka, F. A.; Denton, C. A. and Ringel, S. J. 1947. The methionine and cystine content of hen's eggs. The Journal of Biological Chemistry 169:259-265.

Csonka, F. A. 1950. Nitrogen, methionine and cystine content of hen's eggs. Their distribution in the egg white and yolk. The Journal of Nutrition 42:443-451. https://doi.org/10.1093/jn/42.3.443

Dymond, J.; Vinyard, B.; Nicholson, A. D.; French, N. A. and Bakst, M. R. 2013. Short periods of incubation during egg storage increase hatchability and chick quality in long-stored broiler eggs. Poultry Science 92:2977-2987. https://doi.org/10.3382/ps.2012-02816

Güçlü, B.; Uyanık, F. and İșcan, K. 2008. Effects of dietary oil sources on egg quality, fatty acid composition of eggs and blood lipids in laying quail. South African Journal of Animal Science 38:91-100.

Hammershøj, M. and Johansen, N. F. 2016. The effect of grass and herbs in organic egg production on egg fatty acid composition, egg yolk colour and sensory properties. Livestock Science 194:37-43. https://doi.org/10.1016/j. livsci.2016.11.001

Han, G.; Yang, H.; Bungo, T.; Ikeda, H.; Wang, Y.; Nguyen L. T. N.; Eltahan, H. M.; Furuse, M. and Chowdhury, V. S. 2018. In ovo L-leucine administration stimulates lipid metabolisms in heat-exposed male, but not female, chicks to afford thermotolerance. Journal of Thermal Biology 71:74-82.

Haron, A.; Dahan, Y.; Shinder, D. and Druyan, S. 2017. Physiological effects of hypoxic conditions during the plateau period on the chicken embryo. Comparative Biochemistry and Physiology Part A: Molecular \& Integrative Physiology 203:32-39. https://doi.org/10.1016/j.cbpa.2016.08.015

Heo, J. M.; Woyengo, T. A.; Kahindi, R. K.; Kiarie, E.; Maiti, P. K. and Nyachoti, C. M. 2015. Ileal amino acid digestibility in egg from hyperimmunized-hens fed to weaned pigs and piglet response to diets contain egg products. Animal Feed Science and Technology 204:52-61. https://doi.org/10.1016/j.anifeedsci.2015.03.006

Kermanshahi, H.; Golian, A.; Emami, N. K.; Daneshmand, A.; Tabari, D. G. and Ibrahim, S. A. 2017. Effects of in ovo injection of threonine on hatchability, intestinal morphology, and somatic attributes in Japanese quail (Coturnix japonica). Journal of Applied Animal Research 45:437-441. https://doi.org/10.1080/09712119.2016.1206902 
King, E.; Hugo, A.; De Witt, F.; Van der Merwe, H. and Fair, M. 2012. Effect of dietary fat source on fatty acid profile and lipid oxidation of eggs. South African Journal of Animal Science 42:503-506.

Kraisoon, A.; Navanukraw, C.; Inthamonee, W. and Bunma, T. 2018. Embryonic development, luteal size and blood flow area, and concentrations of $\mathrm{PGF}_{2 \alpha}$ metabolite in dairy cows fed a diet enriched in polysaturated or polyunsaturated fatty acid. Animal Reproduction Science 195:291-301. https://doi.org/10.1016/j.anireprosci.2018.06.007

Li, F.; Mou, S. Y.; Liu, Y.; Jiang, D.; Wang, C.; Chen, Y. L.; Ren, H. L. and Xu, L. M. 2018. Maternal dietary energy levels affected the lipid deposition of offspring embryos at the end of the laying period of broiler breeder hens. Italian Journal of Animal Science 17:180-183. https://doi.org/10.1080/1828051X.2017.1345665

Li, F.; Shan, A. S.; Hu, J. W.; Zheng, Y. B.; Xu, L. M. and Chen, Z. H. 2013. Changes to daily feed intake during the laying period alters embryonic MSTN and MYOG gene expression in genetically fat and lean lines of chickens. British Poultry Science 54:728-737. https://doi.org/10.1080/00071668.2013.853868

Li, F., Shan, M. X.; Gao, X; Yang, Y.; Yang, X.; Zhang, Y.Y.; Hu, J.W.; Shan, A. S. and Cheng, B. J. 2019. Effects of nutrition restriction of fat-and lean line broiler breeder hens during the laying period on offspring performance, blood biochemical parameters, and hormone levels. Domestic Animal Endocrinology 68:73-82. https://doi.org/10.1016/j.domaniend.2019.01.007

Li, F.; Xu, L. M.; Shan, A. S.; Hu, J. W.; Zhang, Y. Y. and Li, Y. H. 2011. Effect of daily feed intake in laying period on laying performance, egg quality and egg composition of genetically fat and lean lines of chickens. British Poultry Science 52:163-168. https://doi.org/10.1080/00071668.2011.559455

Lima, R. C.; Fuentes, M. F. F.; Freitas, E. R.; Sucupira, F. S.; Moreira, R. F. and Braz, N. M. 2007. Farelo de coco na ração de poedeiras comerciais: digestibilidade dos nutrientes, desempenho e qualidade dos ovos. Revista Brasileira de Zootecnia 36:1340-1346. https://doi.org/10.1590/S1516-35982007000600016

Trindade Neto, M. A.; Pacheco, B. H. C.; Albuquerque, R. and Schammass, E. A. 2011. Lysine and zinc chelate in diets for brown laying hens: effects on egg production and composition. Revista Brasileira de Zootecnia 40:377-384 https://doi.org/10.1590/S1516-35982011000200020

Nimalaratne, C.; Lopes-Lutz, D.; Schieber, A. and Wu, J. 2011. Free aromatic amino acids in egg yolk show antioxidant properties. Food Chemistry 129:155-161. https://doi.org/10.1016/j.foodchem.2011.04.058

Noiva, R. M.; Menezes, A. C. and Peleteiro, M. C. 2014. Influence of temperature and humidity manipulation on chicken embryonic development. BMC Veterinary Research 10:234. https://doi.org/10.1186/s12917-014-0234-3

Prezotto, L. D.; Camacho, L. E.; Lemley, C. O.; Keomanivong, F. E.; Caton, J. S.; Vonnahme, K. A. and Swanson, K. C. 2016. Nutrient restriction and realimentation in beef cows during early and mid-gestation and maternal and fetal hepatic and small intestinal in vitro oxygen consumption. Animal 10:829-837. https://doi.org/10.1017/S1751731115002645

Raja, J. S.; Hoffman, M. L.; Govoni, K. E.; Zinn, S. A. and Reed, S. A. 2016. Restricted maternal nutrition alters myogenic regulatory factor expression in satellite cells of ovine offspring. Animal 10:1200-1203. https://doi.org/10.1017/ S1751731116000070

Salter, D. N.; Coates, M. E. and Westgarth, D. R. 1971. Studies on the incorporation of ${ }^{14} \mathrm{C}$-labelled amino acids into egg proteins. British Poultry Science 12:483-498. https://doi.org/10.1080/00071667108415904

Surai, P. F.; Fisinin, V. I. and Karadas, F. 2016. Antioxidant systems in chick embryo development. Part 1. Vitamin E, carotenoids and selenium. Animal Nutrition 2:1-11. https://doi.org/10.1016/j.aninu.2016.01.001

Vilchez, C.; Touchburn, S. P.; Chavez, E. R. and Chan, C. W. 1990. The influence of supplemental corn oil and free fatty acids on the reproductive performance of Japanese quail (Coturnix coturnix japonica). Poultry Science 69:1533-1538. https://doi.org/10.3382/ps.0691533

Vilchez, C.; Touchburn, S. P.; Chavez, E. R. and Chan, C. W. 1992. Effect of feeding palmitic, oleic, and linoleic acids to Japanese quail hens (Coturnix coturnix japonica). 2. Maternal diets and stage of incubation on the lipid metabolism of quail embryos. Poultry Science 71:1032-1042. https://doi.org/10.3382/ps.0711032

Wang, H.; Wang, Q.; Wang, S.; Hu, G. and Li, H. 2009. Comparative analysis of body fat traits and serum biochemical parameters between broiler lines divergently selected for abdominal fat content. Journal of Northeast Agricultural University 40:76-80.

Yin, Q.; Han, Y. and Zhang, Z. Y. 1996. Studies on the requirements and models of essential amino acids and protein in the peak for laying hens. Journal of Northeast Agricultural University.

Yildirim, I. and Yetisir, R. 2004. Effects of different hatcher temperatures on hatching traits of broiler embryos during the last five days of incubation. South African Journal of Animal Science 34:211-216.

Zhan, X. A.; Wang, M.; Ren, H.; Zhao, R. Q.; Li, J.X. and Tan, Z. L. 2007.Effect of early feed restriction on metabolic programming and compensatory growth in broiler chickens. Poultry Science 86:654-660. https://doi.org/10.1093/ps/86.4.654

Zhao, L. Y.; Xu, S. Q.; Zhao, R. Q.; Peng, Z. Q. and Pan, X. J. 2010. Effects of selenium and methionine supplementation of breeder hen diets on selenium concentration and oxidative stability of lipids in the thigh muscles of progeny. Journal of Food Science 74:C569-C574. https://doi.org/10.1111/j.1750-3841.2009.01296.x

R. Bras. Zootec., 48:e20180292, 2019 